\title{
THE RELATIONSHIP BETWEEN PHYSICAL DISABILITY AND THE DIDACTIC PRINCIPLES OF CONSTRUCTIVIST PEDAGOGY IN ANCIENT GREEK EDUCATION, MAINLY IN PHYSICAL EDUCATION
}

Szerzők:

Renáta Ildikó Hegedûs

Eszterházy Károly University

Dóra Roszik

University of Szeged

Első szerző e-mail címe:

hegedusrenataildiko@gmail.com
Lektorok:

Nóbik Attila (PhD, habil.)

Szegedi Tudományegyetem

Pető Bálint (PhD)

Szegedi Tudományegyetem

és további két anonim lektor...

\begin{abstract}
Absztrakt
AZ ANTIK GÖRÖG FÖKÉNT A TESTI NEVELÉSBEN MEGJELENŐ KONSTRUKTIVTSTA PEDAGÓGIA DIDAKTIKAI ELVEI ÉS A TESTI FOGYATÉKOSSÁG KAPCSOLATA
\end{abstract}

A tanulmány célja, hogy Hegedűs (2020) művének gondolatmenete alapján bemutatásra kerüljenek az antik görög (spártai, athéni) nevelés legfontosabb elemei, melyben a testi nevelés és harcedzettség kiemelt szerepet kapott. Azonban ennek okán érdemes kitérnünk azokra a személyekre és nevelésükre, akik valamilyen testi eltéréssel fogyatékossággal jöttek a világra. Továbbá a vizsgálat alá vont időszakban folytatott nevelési, oktatási tevékenységek bemutatásával megkíséreltük bemutatni azokat a konstruktivista didaktikai elveket, melyek kapcsolatba hozhatók az antik korra jellemző neveléssel.

Kulcsszavak: konstruktivista pedagógia, konstruktivizmus, testi fogyatékosság, fogyatékosság történet, neveléstörténet

Diszciplína: pedagógia, pszichológia

\section{Abstract}

The aim of our study is to present the most important elements of ancient Greek (Spartan, Athenian) education, in which physical education and martial arts were given a 
prominent role, based on the aspect of Hegedűs' (2020) work. However, for this reason, it is worth mentioning those individuals and their education who were borne with some limitation or physical disability. Furthermore, by introducing the educational activities carried out in the examined period, we tried to present the constructivist didactic principles that can be related to the education characteristic of the ancient age.

Keywords: constructivist pedagogy, constructivism, physical disability, disability history, history of education

Disciplines: pedagogy, psychology

Hegedűs, Renáta Ildikó \& Roszik, Dóra (2021): The Relationship Between Physical Disability and the Didactic Principles of Constructivist Pedagogy in Ancient Greek Education, Mainly in Physical Education. OxIPO - interdiszciplináris tudományos folyóirat, 2021/2, 45-57. doi: 10.35405/OXIPO.2021.2.45

As Hegedûs (2020) points out, the most important elements of the formation and development of European culture can be related to the ancient Greeks. Hegedûs (2020) quotes Pukánszky (1997), who presents Nietzsche's reasoning in his book about the history of education:

"Greeks gradually learned how to organize chaos ... and let their apparent needs die. Thus they took possession of themselves again; they did not remain the overstated heirs and epigones of the whole East for long; moreover, they have become, at the cost of a serious struggle ... the happiest enrichments of the inherited treasure, and the firstborns and role models of all future cultural societies" (Nietzsche, 1989, p. 98).

From this reasoning, we can conclude that the Greeks assimilated the masses of different values. These, later harmonized with their own cultural values, were later formed into a system. The formation of the educational customs and traditions of the Greeks was greatly influenced by the geographical endowment of the people. Greek land was made up of units that were isolated from each other. As a result, no larger state units emerged, but the poles provided favorable conditions for the formation of different city-states. This triggered the beginning of social segmentation, which also led to the disintegration of ethnic tribal settings. Called the "superiors", the aristocrats controlled the life of the community in economic, political, and religious terms alike. As a consequence, the aristocratic republic was formed. However, this "supreme" layer was under constant pressure and burden. In the struggles because of territorial acquisitions and 
settlement conflicts, their outstanding abilities had to be proven to the community. Only by this could they gain recognition in material and moral spheres (Pukánszky and Németh, 1997; Hegedűs, 2020).

The Greek poet Homer played a prominent role in the artistic capture of the heroic human ideal. In the work of Pukánszky and Németh (1997), as well as of Hegedûs (2020) it could be read that the famous epic of Homer, Iliad, and later Odyssey, that was also attributed to Homer, were decisive "curricula" in the examined period. Despite these pieces left to us, it can still be said that we know relatively little about the educational practice of this age. On the other hand, we can clearly conclude that the physical strength and dexterity required for martial arts were indispensable, as their level influenced the outcome of the wars. The important role of physical strength and outstanding physique related to martial arts can be clearly demonstrated. In this context, however, it is worth looking at people who were born with physical disability.

The words of Plato and Aristotle appear in the works of Kálmán and Könczei (2002) and Adél Magyar (2017). Plato and Aristotle, the justly famous philosophers, also spoke in support of the elimination of the hindering factors, that is, those born with disability.

In the present case, the Spartan practice, also presented later in the study, sentencing to death children who appear to be "weaker" and "unviable". Physical disability is obvious at first glance, so presumably the fate of a child born with this type of disability was decided at birth. A child born with a visible physical deficit, disability, or deviation is clearly sentenced to death by Plato. To quote Plato: "those who were born scrubby should disappear in an inaccessible, secret place according to its order and manner" (Állam, 460c). It also appears in the writings of Aristotle that he himself does not reject this practice, that is, covert murder and exposure. To quote Aristotle: "no bastard should be raised" (Politika, 1335b).

Based on the sources studied so far, we can conclude that we do not have too much information - not even in the field of education - about children and people with disabilities. Teaching by living example was used in education and upbringing in the examined period. The elderly enjoyed unconditional respect as they helped develop the skills of the young. However, the role of the family was primary. It also counted as the primary scene of education and the mother herself as the primary teacher. The education of the girls did not even move to a higher level. The poems presented earlier outline the demands for girls. These included taking care of things around the house. However, moral virtue and unquestionable marital fidelity were more important than this (Pukánszky and 
Németh, 1997; Hegedűs, 2020). In this introduction, we covered the basics of ancient Greek education, but in the following chapters the elements of Spartan and Athenian education, mainly physical education, and their relationship to physical disability are presented in more detail. As well as the didactic principles of constructivist pedagogy that are related to physical education.

\section{Basics of Spartan education}

Spartan education is closely linked to adaptation to geographical conditions. The conquering "Spartans" — who were part of the Doric tribes - settled in an area surrounded and enclosed by swampy and mountainous countryside. Forcing helots into slavery and disenfranchisement (Pukánszky and Németh, 1997; Hegedűs, 2020).

In the work of Pukánszky and Németh (1997) it can be read that the power of the military aristocracy was based on the laws consecrated to Lycurgus. The law clearly sets out an instruction on education that the children of the country should receive a uniform and state education. The primary goal of education is to maintain constant combat readiness in line with the state system. By this time, Sparta had embraced the military image as known later. However, the exact date of the beginning of the educational system cannot be determined. In his writing, Prohászka (2003) concludes that it started at the end of the 8th century and the beginning of the 7 th century. Defending the ruling position in Sparta was a primary goal. For this reason, the goal was to educate and shape ruthless warriors. This action was necessary due to the small extension of the ruling class.

They had to be prepared for the thousands of helots living in constant rebellion. Total repression of individuality was not a special case in upbringing of children. Plutarch's work, the Parallel Biographies reveals that the image of a city could best be likened to a military camp. The polis is the first; every citizen lives for the polis and not for himself. From these words we can deduce the characteristics of the Spartan warrior. The role of the following three traits is essential: physical strength, fitness, fanaticism. The sources as well as the work of Prohászka (2003) also suggest that Sparta showed the image of a camp in constant combat readiness. The importance of military education is outstanding, and so is the education of the body itself.

In its own way, Spartan education and the way of life associated with it were unique in ancient times. The quest to build and maintain a strong community spirit can be seen as unique (Hoffmann, 2009). The primary scene of Spartan education was the family. The children were raised next to their mother until the age of seven. After that, they got to the field of common education, that is, to camps. They were divided into different 
groups in the camps. The most fit and sensible boys acted as group leaders. They walked barefoot, and their hair cut. From the age of twelve, children had to walk unwashed and in the same cloak (Pukánszky and Németh, 1997; Hegedűs, 2020). In summary, Spartan boys and men lived a significant part of their lives in military camps between the ages of 7 and 30. This is due to proper education and training. The Spartan man spent most of his day in camps even after the age of 30; but he was already able to start an independent household (Hoffmann, 2009). The goal of primary education was to learn unconditional obedience and to tolerate physical pain well. Furthermore, to stand up boldly in the fight. In the work of Pukánszky and Németh (1997) it is clear that physical education and upbringing play a prominent role, while mental education does not. Based on this, we can say that Spartans have minimal training on their intellectual skills. It was not necessary to master reading or writing, but they sought to express their thoughts in a precise, clear, and understandable way (Pukánszky and Németh, 1997). Strict discipline prevailed in upbringing and education, in which discipline and punishment often went hand in hand. There were various initiation ceremonies associated with becoming a man. These were first possible at the age of 17 . During the initiation, flogging was considered common and its success depended on the candidate's ability to quietly tolerate the pain. He was considered a man only if he had succeeded in accomplishing this (Hoffmann, 2009).

Unconditional obedience was also dominant in education. Obedience has also been demonstrated by various practices. The best-known practice is concealment, also called a secret mission, which was essentially a cruel "massacre" in the camp of slaves, regardless of gender or age. The education of the girls can be considered the merit of the Spartans. However, the primary goal of women's education was to enable their future children to conceive in a strong, healthy, and trained body. They received similar training in terms of physical education as men. These were also needed to be able to protect the home during a campaign (Pukánszky and Németh, 1997; Hegedűs 2020).

\section{The relationship \\ between Spartan education and physical disability}

Exploring the characteristics presented earlier, it is worth looking at the phenomenon of physical disability and its assessment. The texts quoted earlier from the works of Aristotle and Plutarch also support the fact that physical disability and deficit appeared. These traits and adjectives were identified and associated with the words "awkward" and "crippled". A person with a disability, including a physical disability, does not 
benefit either the individual or the state. The works of Kálmán \& Könczei (2002) and Magyar (2017) also refer to Plutarch. The tradition developed in Sparta in the age of Lycurgus that the authors described as the opposite of institutional assistance for children born with disabilities is the following: "The father did not have the newborn baby but took it in his arms and brought it to a place called Lesche, where the elders of the tribes gathered and examined the little one. If it was a healthy and strong infant, they instructed the father to raise him, and at the same time assigned him one of the nine thousand Spartan parcels. But if it was indifferent or crippled, it was thrown into the abyss of Taigetos called Apothetai - with the conviction that it is not in the best interest of either the child or the state for a weak and unviable person to survive. That's why women bathed the newborn in wine and not water to test the endurance of her body. If the child had epilepsy, some weakness, or sick body, he got a spasm from the strong wine and died, but if he was healthy, he became even more muscular." (Lükurgosz, 16, 1-3. - translated by Elek Máthé) (Kálmán and Könczei, 2002)

As Hegedűs (2020) suggests, this Spartan practice was not considered unique. It is not only here that the act of removing the child can be discovered. According to Hoffmann (2009), the widespread belief that infants were thrown into a chasm does not hold its place. Before being sentenced to death, the last "option" was to put the babies to a place on Mount Taygetos called Apothetai, who, more fortunately, could get to childless families or in the worst case, into the hands of slave traders or procurers. In her work, Magyar (2017) suggests that the habit of bathing in wine was the first real big physical test for a Spartan child if he had not been sentenced to exposure before. Also in this case, survival can be related to the physical ability and not to the decisionmaking of gods or "elders of tribes". However, it is important to point out that Sparta operated as the only city-state where laws regulated the exposure of children, i.e., “child selection". In accordance with this law and custom, a body, i.e., the "elders of the tribes," made a judgment about the child's future.

Adél Magyar (2017) refers to postnatal birth control by presenting the contemporary mentality. This "child selection and regulation" can also be considered a popular topic in the literature of general pedagogical history and childhood studies.

It is not necessary in the present study to describe the system of "sacrifice" used in different ages and cultures, but we briefly discuss the viewpoint of the Swiss theologian Christina Tuor-Kurth.

According to Christina Tuor-Kurth, the destruction and exposure of infants can be considered a common "cultural phenomenon" in contemporary societies. 
In general, poverty and the several children born to a poor family related to it, comfort of wealthier parents, poor physique, and visible physical disabilities are among the reasons. However, in her work, he refers to the guilt and shame developed in parents that followed the exposure and murder (Tuor-Kurth, 2010, pp. 16-17).

\section{Basics of Athenian education}

The mode of education in Athens developed differently from that of the Spartans. In his book titled The Peloponnese War, Thucydides quotes Pericles as an excellent Athenian statesman: "Their upbringing is characterized by the fact that they have been training themselves with tireless exercises from an early age for masculine courage, however, we live in a freer way, but we can face the same dangers with no less determination... And that we are preparing to overcome dangers with an easier way of life rather than tiring practices, and not with the courage instilled in us by the laws, but primarily borne with us, it has the advantage that we do not anticipate the trials that are yet to come. But if we are in them, we do not show less heroism than those whose whole lives are spent in labor."

From these lines we can conclude that the Athenians wanted to create a man striving for harmony and living in harmony through education. In addition to the intellectual ability, moral sense, and receptivity to beauty of a person living in harmony, his courage is also outstanding. With these characteristics, he was able to compete with a Spartan warrior if necessary (Hegedûs, 2020).

Athens was in a better position than the Spartans in terms of its political position. Its reason is that there were not many uninhabited settlers - the metics - and slaves. The polis was headed by the citizens with the highest incomes, the Hellenic-born aristocrats. "Talking tools", also known as slaves, had no rights. The best state leaders - like Draco, Solon, or Pericles, mentioned earlier - sought to make culture and arts available to the people. Therefore, significant sacrifices were also made. It is salient that, unlike in Spartan education - however, without legal regulations - everyone could "requisit" education. The goal of the wealthy was to raise and "create" a "good polis citizen" who had both professional and general education. Knowledge, especially professional knowledge, was passed down by parents to their children. A profession passed from father to son, while the transmission of general education was the responsibility of the nurse, the mother, the educator, and also the father. The educated man had to acquire many knowledge. He had to know the history of his people, the works of classical writers and poets, and the legends of mythology. In addition to this knowledge, a good polis citizen was 
characterized by an argumentative and logical way of thinking who could take part in reasoning and discussion. At the age of seven, family education was followed by a private teacher, similar to the Spartans. The components of the education consisted of muse and gymnastics training. The muse training covered a) grammar-literature training, which included reading, writing, arithmetic and study of literary works, and b) kithara training, which included learning sung poems with music and dancing as well. (Pukánszky and Németh, 1997; Hegedűs, 2020). Pukánszky and Németh (1997) also mention different types of schools which are: grammatical "school", kithara "school", palaistra, gymnasium.

For the purposes of the present study, we aimed to present and describe the schools related to physical education, as it also plays an important role in Spartan education. In the place designated for wrestling - in the palaistra -, children started gymnastics training from the age of seven, which was mainly limited to gymnastics and exercise (Pukánszky and Németh, 1997; Hegedűs, 2020). In his work, Prohászka (2003) referred to the exercise teacher as a paidotribes or gymnast. The boys performed exercises with uncovered body and accompanied by music.Running and wrestling were the main exercises, but jumping, discus and javelin throwing also appeared (Prohászka, 2003; Hegedűs, 2020). The seniors continued exercising in the gymnasium. The building consisted of running tracks - indoors and outdoors -, and rooms for changing and bathing were also designed. Lecture halls and libraries had been developed later (Pukánszky and Németh, 1997; Hegedűs, 2020).

It is clear that the Athenians also gave priority to the issue of physical education, just like the Spartans. The principle of "kalokagathia" was followed. According to this, "beauty" and "goodness" exist in a harmonic unity. However, the primary purpose of the Spartans and Athenians was not the same. While the goal of the Spartans was to train battle-tested soldiers, the Athenians aimed to create an aesthetic and harmonious body. Physical education focused not only on strengthening the physique, but on its secondary benefits. According to this, by strengthening the physique, the virtues of willpower, selflessness, and self-sacrifice begin to develop. Their ideal is a simple man who can become a hero if needed. A sharp contrast can be seen here in the upbringing of the two nation. In the case of Spartan upbringing, physical coercion prevailed clearly. Athenians believed that they could penetrate deeper into the child's soul by aesthetics (Pukánszky and Németh, 1997; Hegedűs 2020).

\section{The relationship between Athenian education and physical disability}

In the work of Kálmán and Könczei (2002), we find an indication that another 
practice preceded the "habit" of exposing and throwing children into crevices. It was customary for the Greeks to introduce the newborn child to his father, who could decide about the fate of his child. He undertook to raise the child, or he could expel it. Based on this, we can say that some forms of "child selection", that manifested mostly in the exposure, were always closely related to the life and customs of the Greeks.

Magyar (2017) also reaches this conclusion in her work and quotes the thoughts of Plato and Aristotle. Examining Athenian education, we can conclude that where aesthetics plays a prominent role, the appearance of a distorted, damaged and disabled body may not necessarily could "coexist". It is likely that a negative mental picture developed in both children and adults about physical disabilities at the examined age. Hegedűs (2020) quotes Hoffmann (2009), saying that the primary and main goal of their education is to make the human body beautiful, proportional, and strong. In addition to realizing the ideal of kalokagathia, they believed that the body is the abode of the soul, so it must be especially beautiful. Secondly, a strong and muscular body was expected from a man performing military service, but this did not manifest to the same extent as in Spartan thinking. A healthy and beautifully crafted body has proportional body parts. The movements of a person with such abilities are light, harmonious and rhythmic. He provides a pleasant and beautiful appearance.

\section{The principle of constructivism, constructive pedagogy}

In order to define the constructive "elements" that appear in ancient Greek education, it is essential to clarify some basic concepts. First, we describe the principle of constructivism. Virág (2013) refers to the work of Nahalka (2002) and uses the following definition. The principle of constructivism is that we create knowledge ourselves. It does not flow into us from some external source. Earlier epistemological trends and their representatives represented that knowledge is objective, both its process and its outcome. This was justified by the fact that it can be derived from a reality outside of us, which is objective. Man is considered a passive participant in the process. It is important to emphasize that constructivism does not deny the importance of the interactions between the cognitive system and the environment.

It is also important for the present study to highlight that constructionism proclaims the primacy of culture and social environment. According to this view, an individual can be identified on the basis of culture. We can only be able to interpret other people's constructions based on social conventions. The existence of conventions is not denied by constructivism either, but according to its 
view, they can only be found in the individual. Acquisition of knowledge is tested in the social interactions in which the child or student participates. As a second concept, we turn to constructivist pedagogy. According to Nahalka (2002) its definition is the basic idea of constructivism itself. In another words, trying to incorporate new information into our prior knowledge system. Constructive pedagogy originates from the prediction-action-feedback-prediction cycle. The principles of constructivist didactics, according to Nahalka (2002), can be deduced from the basic idea of constructivism. These are the following: teaching as creating learning environments, problem solving, structure of knowledge systems, importance of prior knowledge, contextual principle, principle of multiple approaches, differentiation, assessment processes.

The didactic principles of constructivist pedagogy and their appearance in ancient Greek education

Some principles are defined below, and then the fit of these didactic principles to ancient Greek education is presented.

Teaching as creating learning environment: The constructional processes of knowledge created by the student are at the heart of the learning process. The expert educator who is an element of the learning environment in this case is responsible for shaping the community. The concept of learning environment introduced by constructivism: "[...] it is a system that integrates all the important factors influencing the learning process, within the framework of which real school learning takes place." (Nahalka, 2002, p. 66). The learning environment always seeks to develop problem-solving skills for a specific area of specialized knowledge by creating lifelike contexts (Virág, 2013). The educator with expertise in ancient Greek education could have been both an educator and a senior citizen of the given age. While in the case of girls it was limited to parents and nurses. We can look at an environment that develops skills for a special area of knowledge (in ancient times, the most militant citizen, soldier) by the different types of "Athenian schools".

The importance of prior knowledge: Prior knowledge determines the process and purpose of teaching. The teacher needs to be aware of the content and mobility of the child's prior knowledge. According to traditional didactics, the child starts with a clean sheet, with a "tabula rasa", which will be filled with education. However, according to constructivism, the child already carries a model in his head at birth. He tries to interpret the new knowledge based on this (Virág, 2013). Prior knowledge was passed down from teachers, senior polis citizens and deservedly famous philosophers. In the case of the Athenians, the ideal of kalokagathia, the symbol of knowledge and aesthetics of the body, can be seen as 
prior knowledge. Inherited views, which was applied to people with physical disabilities, can also be considered prior knowledge.

Contextual principle: In the contextual principle, students always encounter new knowledge in lifelike situations. These situations are related to the child's deepest knowledge. As a result, new knowledge will be more easily retrievable in the future in lifelike situations or in real life (Virág, 2013). The Spartan practice essentially a cruel massacre regardless of sex and age -, which was also called a secret assignment as a practice of hiding and survival, can be considered a realworld context.

Differentiation: Differentiation is a process organization principle that takes into account different student knowledge and possible negative differences. When organizing the learning process, care should be taken to make the most of it, based on one's own abilities. As a result, there is no common curriculum, no uniform goals or requirements, only a differentiated system of activities that allows for optimal development (Virág, 2013). Differentiation presumably did not appear in the ancient Greeks. This is true for both physical education and the physically disabled. A good citizen must serve the interests of the state. However, physical strength and fitness are essential to the service of the state.

Assessment: In constructivist pedagogy, evaluation applies to both the work of the teacher and the performance of the child. The contextual principle mentioned earlier (based on realistic situations) should also be reflected in the evaluation. The teacher has no direct influence on the construction processes; therefore, the student's self-assessment plays a prominent role. The way in which knowledge is measured in traditional numbers and related to classification is almost incompatible with constructivism (Virág, 2013). The evaluation processes appeared in the examined period indeed. The younger ones were faced to a number of trials. The results of these, whether negative or positive, were evaluated in any case. An example is the ritual of becoming a man. In this ritual, the young man was flogged and became a complete human being only if he could tolerate it quietly, and without a word.

\section{Summary}

In conclusion, the concept and the fact of physical disability were not new to the ancient Greeks. This is proved by the resources available to us and processed by us. Based on these, it is likely that people with physical disabilities were titled with words such as "crippled" and "indifferent". Today, of course, these adjectives are out of use, but it was important for our research to clarify them. Physical disability was considered a problem by the ancient Greeks. A problem that is detrimental to both the individual and society. Therefore, people 
with this type of disability were often sentenced to death by different types of "child selection" practices. Children with disabilities who survived, presumably did not receive education. Our study also presented some didactic principles of constructivism and constructivist pedagogy that we linked to ancient Greek education and physical disability. These principles were illustrated through examples. The emergence of physical disability as a problem has also been demonstrated through these. One of the didactic principles of constructivist pedagogy - context principle - would be presented as an explanation. According to the principle of adaptation to life, it seems unrealistic for a person with a physical deficit to implement the "practice of hiding" because his or her physical abilities do not allow it. Another example is the principle of differentiation, which probably did not appear at all in education. Like the previous example, it doesn't seem realistic either. Nor can it be thought that a Spartan, who is characterized by physical health, fitness, and fanaticism, should be relieved of his duties because of his poor health status or weak physique. Furthermore, we sought to present the didactic principles of constructivist pedagogy in order to place it in a kind of educational history framework. Our goal is to expand the literature on the history of education and the history of disability.

\section{References}

Arisztotelész (national edition: 1994): Politika. Gondolat kiadó, Budapest.

Hegedûs, R. I. (2020): Az európai kultúra bölcsőjénél megjelenő nevelés bemutatása kiemelt figyelmet szentelve a testi fogyatékosok nevelésére. OxIPO - interdiszciplináris tudományos folyóirat, 2020/2, 9-20. doi: 10.35405/OXIPO.2020.2.9

Hoffmann, Zs. (2009): Antik nevelés. Iskolakultúra-könyvek 35. Veszprém. Homérosz (national edition: 1981): Iliász, Book XIX. Budapest, 45.

Homérosz (national edition: 1974): Odüsszeia. Budapest.

Kálmán, Zs., \& Könczei, Gy. (2002): A Taigetosztól az esélyegyenlöségig. Osiris Kiadó, Budapest.

Magyar, A. (2017): Fejezetek az értelmifogyatékeosság-kép történetéböl Elzárás, gyógyitás, fejlesztés a keqdetektöl a 19. század végéig. Gondolat Kiadó, Budapest.

Nahalka, I. (2002): Hogyan alakul ki a tudás a gyerekekben? Konstruktivizmus és pedagógia. Nemzeti Tankönyvkiadó, Budapest.

Nietzsche, F. (1989): A történelem hasznáról és káráról. Akadémiai Kiadó, Budapest.

Platón (national edition: 1983) Az állam. In: Platón válogatott múvei. Európa Kiadó, Budapest.

Plutarkhosz (national edition: 1978): Párbuzamos életrajzok. Magyar Helikon, Budapest.

Prohászka, L. (2003): Az európai ókor neveléstörténete. In: Orosz, G. (ed.) 
Az európai ókor neveléstörténete. Probászka Lajos egyetemi elóadásaiból I. Debreceni Egyetem Bölcsészettudományi Kar Neveléstudományi Tanszék, Debrecen.

Pukánszky, B., \& Németh, A. (1997): Neveléstörténet. Nemzeti Tankönyvkiadó, Budapest.

Thuküdidész (national edition: 1985): $A$ peloponnészoszi háború. Európa, Budapest.
Tuor-Kurth, C. (2010): Kinderaussetzung und Moral in der Antike. Jüdische und christliche Kritik am Nichtaufriehen und Töten neugeborener Kinder. Vandenhoeck \& Ruprecht, Göttingen.

Virág, I. (2013): Tanuláselméletek és tanitásitanulási stratégiák. Eszterházy Károly Főiskola, Eger 